\title{
Embryo Coculture: Sequential Transfer and Blastocyst Freezing
}

\author{
A. Bongso, C.Y. Fong, S.C. Ng, S.S. Ratnam
}

\begin{abstract}
Abstrak
Walaupun banyak usaha telah dilakukan selama 15 tahun setelah dilahirkannya bayi tabung pertama di dunia, keberhasilan angka kehamilan buatan ini masih rendah. Pada saat ini penempatan blastosis di muka tuba lebih disukai dari pada di uterus, akan tetapi ternyata teknik ini masih menghasilkan kejadian abortus yang cukup tinggi. Banyak peneliti menyatakan metoda 'coculture' mempuny'ai tingkat keberhasilan untuk mendapatkan angka blastulasi yang lebih tinggi (70\%) dibanding dengan metoda kultur konvensional (25-30\%). Hal ini dimungkinkan karena pada cara ini dipilih blastosis yang baik dan sehat serta mampu membelah dengan kecepatan yang mendekati keadaan alami di dalam tubuh manusia. Makalah ini membahas kemungkinan penggunaan teknik pelepasan blastosis secara bertahap, untuk meningkatkan angka keberhasilan kehamilan buatan.
\end{abstract}

\begin{abstract}
Even though many efforts have been done for fifteen years since the birth of the world's first test tube baby, the rate of assisted reproductive delivery was still low. Nowadays, rubal replacement procedure becomes more popular than the uterine transfer. However, this technique still ends up with a very high incidence of abortion. Many workers claimed that coculture system resulted in more prominent blastulation rates (70\%) as compared to the conventional method (25-30\%). This is due to the possibility to select the good, healthy blastocysts which can cleave at a speed comparable to in vivo fining. This paper discusses the possibilities of sequential two-stage transfer, blastocy'st transfer and blastocyst freezing that may eventually lead to improve the success of the delivery rates.
\end{abstract}

Keywords : Assisted reproductive technique, embryo co-culture, blastocyst transfer, blastocyst freezing

The delivery rates in assisted reproduction have been disappointingly low even though it has been over 15 years since the birth of the world's first test tube baby. Tubal replacement procedures appear to yield better results than uterine transfers in large sample sizes ${ }^{1}$ thus endorsing the fact that the tubal environment may be playing a role in improving the viability of replaced 2-pronuclear (2PN) to 4-cell stage embryos. However even such tubal transfers end up in a very high incidence of abortion resulting in sub-optimum delivery rates. Embryo viability defined as the ability to implant or sustain implantation to term is thus questioned for 2PN to 4-cell stage embryos produced under conventional culture conditions of liquid culture media, temperature and gas environment. Improved culture systems such as coculture have been reported by many workers to generate blastulation rates of as high as $70 \%$

Department of Obstetrics \& Gynaecology, National University of Singapore, National University Hospital, Lower Kent Ridge Road, Singapore 0511

Presented at XVth Asian and Oceanic Congress of Obstetrics and G)necology, October 15-20, 1995, Bali, Indonesia compared to lower rates (25\%-30\%) in culture media. The quality of such blastocysts based on morphology and cleavage speeds can be categorised. It is presumed that if embryos could survive up to 5 days in vitro, produce a good healthy in her cell mass and trophoectoderm and cleave at speeds comparable to in vivo finings, their viability would be better and improved implantation rates would be expected. This paper discusses the possibilities of sequential two-stage transfer, blastocyst transfer and blastocyst freezing that may eventually lead to improvement and the success to Assisted Reproductive Technique (ART).

\section{BLASTOCYST TRANSFER}

In farm, animal embryo transfer programs fertilization is takes place in vivo in the fallopian tubes of the donor animal and blastocysts flushed out of her uterus. The flushed blastocysts are then transfered into recipient animals resulting in take-home baby rates of as high as $50 \%$ to $60 \%$. It is extremely difficult to understand why if blastocysts are replaced in the human the results would be different because cleavage and early 
embryonic development are virtually similar in both man and farm animals.

If human embryos are kept for prolonged periods in culture they can produce blastocysts at variable times ranging from Day 5 to 7 postinsemination. The morphology of such blastocysts vary, with some possessing distinct inner cell masses (ICM) and well laid down trophoectoderm (TE) while others do not. Dokras et al ${ }^{2}$ recently suggested a grading system to delineate the good from bad blastocysts. Those that started to cavitate on Day 5 and had clear ICM and TE were the best blastocysts (BG1). Some blastocysts were produced on Day 5 with a large blastocoele but had concave borders with no distinct ICM. These blastocysts were considered "transitional" or "slow developers" and became BG1 blastocysts on Day 6 which were also considered of good quality (BG2). The poorest were BG3 blastocysts that were produced on Day 6 and had dark granular multiple degenerative foci in the ICM. Their blastocoels collapsed within 24 hours and degeneration took place thereafter.

Because of such a variation in morphology and cleavage timings it is not clear which of the blastocyst grades would be most viable but it is understood that the closer in vitro cleavage speeds are to in vivo, more viable the embryos will be. Thus the BG1 blastocysts are expected to yield the most viable pregnancies. Other indications of pregnancy potential would be the size and number of cells in the ICM as it has been shown that the greater the total cell number (TCN) the better the quality of the embryo. Hardy et $\mathrm{al}^{3}$ showed that Day 5 and 6 human blastocysts had mean TCNs of 60 and 85 respectively. Although Day 7 blastocysts had a TCN of 120 , the mean dead cell index for Day 7 blastocysts was significantly higher than that of Day 5 and 6 embryos. An increased rate of cell death occurred from Day 7 onwards which may be brought about by suboptimal in vitro conditions or intrinsic factors within the blastocyst. Human chorionic gonadotrophin (HCG) levels in the culture medium in which blastocysts are grown also increased during late preimplantation development and high levels have been used as an indirect measure of blastocyst viability. However, it was reported that such cumulative levels became significant only during Days 8 to 14 post-insemination. $^{2}$ Thus, from a clinical standpoint assessment of HCG in the culture media to predict blastocyst viability may not be useful as blastocysts will usually be replaced on Day 5 or Day 6. More research is therefore needed to produce a reliable non-invasive method of predicting pregnancy potential in blastocysts on Day 5 or Day 6 before replacement.

\section{SEQUENTIAL TWO-STAGE EMBRYO TRANS- FER}

There has been no proper prospective, randomised, controlled clinical trial carried out todate to evaluate the implantation rates of blastocyst transfers in ART programs. Now that improved in vitro systems such as coculture can generate sufficient blastocysts in vitro, it is timely that this study be carried out so as to provide answers as to whether the transfer of late embryonic stages will yield as high delivery rates as that observed in farm animals. No significant difference in pregnancy rates was shown between fresh non-frozen 4-cell and blastocyst stage embryo transfers in a small group of patients. ${ }^{4}$ The blastocysts were generated via culture medium alone without the use of coculture. However, Menezo et $\mathrm{al}^{5}$ using the Vero cell coculture system showed significant differences between cocultured blastocyst stage transfers and cocultured Day 2, 4- cell stage transfers $(52.8 \%$ vs $40.4 \%)$ in 85 patients. These results were on patients with repeated failures at previous IVF attempts. More recently, Frydman et $\mathrm{al}^{6}$ using alsc: Vero cell coculture showed a $32.1 \%$ live birth rate with cocultured blastocyst transfers on Day 5,6 and 7 in 78 patients with repeated failures.

Ideally, BG1 blastocysts should be replaced because this will give the patient a more realistic chance of a pregnancy. Before gaining confidence in blastocyst stage single transfers, an attractive approach is to perform sequential two-stage transfers on Day 2 and Day 5 replacing a maximum transfer of 3 to 4 embryos per cycle. ${ }^{7}$ This would involve initially the transfer of 2 to 3 , 4-cell stage embryos on Day 2 the remaining embryos grown to the blastocyst stage, followed by a second replacement of a single blastocyst on Day 5 .

The Ministry of Health guidelines for ART in Singapore allows the transfer of up to 4 embryos in patients if all the following 3 conditions are satisfied. (i) All children born as a result of the procedure will be cared for in a hospital which has Level 3 neonatal intensive care facilities and (ii) the patient has undergone not less than 2 previous IVF cycles which were unsuccessful and (iii) the patient is over 35 years of age. Sequential embryo transfer was attempted by our group in such patients. Their embryos were cocultured on somatic cells from the $2 \mathrm{PN}$ stage onwards. Passaged cells from human tubal epithelial cells were plated at $1 \times 10^{5}$ cells $/ \mathrm{mL}$ per well in 4-cell plastic culture dishes (Nunclon, Copenhagen), approximately 24 hours before oocyte recovery to ensure that monolayers will be ready 48 hours later for the transfer of 2 PN embryos. 
The medium used initially to plate the cells in this $\mathbf{4 8}$ hours was a commercial Earle's based medium (Medicult, Copenhagen) supplemented with 10\% patient's serum. Serum was needed for maximum plating of cells. On the day of transferring $2 \mathrm{PN}$ embryos to the monolayer, the monolayer was washed and medium replaced with serum-free Medicult supplemented with human serum albumin (HSA) as a protein source so that the embryos get the maximum positive coculture effects from the cells. Thereafter the serumfree medium was replaced every 48 hours until Day 5 (115 hours post-insemination).

If the patient had only 4 fertilized oocytes, then all 4 embryos were replaced on Day 2 as a single transfer into the tubes for TET (tubal embryo transfer patients) or into the uterus for IVF patients. If more than 4 fertilized oocytes were available, then three 4-cell stage embryos were replaced on Day 2 (first transfer) while the remaining embryos were cultured to the blastocyst stage. On Day 5 or Day 6 , a single blastocyst was replaced in a careful second transfer into the uterus in both TET and INF patients. Any surplus blastocysts were frozen for the patient. In uterine transfers, embryos are deposited deep near the fundus of the uterus in the first transfer and just after the internal os of the cervix in the second transfer. Ideally, both transfers must be atraumatic. It would be difficult to say which embryos are implanted, but at least it gives the patient a better chance of a pregnancy because not only early 4-cell stage embryos were replaced but also a hardier blastocyst stage embryo that was able to survive up to 5 days in culture. If no blastocysts are produced by Day 5 , the patient has at least 3 embryos already replaced on Day 2 and the second transfer could be called off. Thus far, 8 out of 19 patients (42\%) who were over 35 years of age and with at least 2 previously failed IVF attempts have become pregnant with this protocol. Large numbers have to be carried out to evaluate the exact success of this procedure. Also, the incidence of multiple pregnancies, abortions and final take home baby rates need to be examined. It has been recently shown that there was a strong positive correlation between a patient's spare embryos developing into blastocysts, if left in vitro, and implantation of her 4-cell stage embryos after transfer in the same cycle. ${ }^{8}$ Thus theoretically, the sequential embryo transfer method should yield a higher implantation rate because both 4-cell and blastocyst stage embryos are replaced in one cycle. Al-Hasani et al ${ }^{9}$ showed in a small series that sequential embryo transfer of noncocultured embryos yielded a clinical pregnancy rate of $40 \%$.
Ideally, blastocyst stage transfers in a single replacement on Day 5 will give the patient a better chance of a pregnancy because as reported by Edwards and Hollands, ${ }^{10}$ only the hardiest embryos would reach this stage and would therefore implant if replaced. The in vitro system however, must be optimal so as to produce a high percentage of blastocysts with confidence so that the patient does not go home disappointed without a replacement on Day 5. Until that confidence is reached, sequential embryo transfer with the gentle and careful skills of replacement may be a good alternative to boost the success of ART. The eventual goal to replace a single viable blastocyst preferably on Day 5 , as this will prevent the risk of multiple pregnancies, yield higher implantation rates, and surplus blastocysts could be frozen for future unstimulated cycles.

\section{BLASTOCYST FREEZING}

It is not known whether optimum implantation rates will be produced after the transfer of a single goodquality blastocyst in a stimulated cycle. Also, would implantation and multiple pregnancy rates increase after the transfer of 2 to 3 blastocysts in a stimulated cycle? The answers to these questions will depend on the quality of the blastocyst [BG1/BG2, Dokras et al] ${ }^{2}$ and the hostility of the endometrium, of a stimulated cycle. It is not known what the results would be if good-quality blastocysts are replaced in a natural or unstimulated cycle as this protocol will simulate the normal physiology of early conception in the fertile woman. To provide answers to this, blastocysts produced from stimulated cycles using improved culture media or coculture will need to be frozen in liquid nitrogen to be later thawed and replaced in an unstimulated cycle.

There have been only a few reports of successful freezing of human blastocysts documented in the literature. It is also not known which blastocyst stage (cavitating, expanded, early hatching) freezes best with optimum results after thawing. Since improved culture systems are now available to generate a fairly high percentage of blastocysts, a reliable method for human blastocyst freezing is urgently needed. The following methods are available with limited experience for blastocyst freezing in the human. More detailed studies are urgently required in this area to arrive at an optimum method for blastocyst freezing.

Successful human blastocyst freezing has been shown by only 3 different groups of workers, each using a slightly different method. 
Method A: ${ }^{11,12}$

Expanded blastocysts were exposed in 5 steps to a final concentration of $8 \%$ glycerol $(1 \%, 2 \%$, $4 \%, 6 \%, 8 \%: 10$ mins each at R.T.). Cooling was from room temperature to $-7^{\circ} \mathrm{C}$ at $-1^{\circ} \mathrm{C} / \mathrm{min}$, followed by seeding $\left(-7^{\circ} \mathrm{C}\right)$, then cooling to $-36^{\circ} \mathrm{C}$ at the rate of $-0.3^{\circ} \mathrm{C} / \mathrm{min}$ followed by plunging into liquid nitrogen at $-196^{\circ} \mathrm{C}$. Thawing was rapid in a waterbath, followed by stepwise removal of the glycerol in 8 steps.

Method B: ${ }^{13}$

Expanded blastocysts were exposed to the same glycerol concentrations as in Method A except that $0.2 \mathrm{M}$ sucrose was added in the final step and the embryos were frozen with sucrose.

Cooling rates were the same as Method A, but thawing was rapid with $0.2 \mathrm{M}$ sucrose added in each step for cryoprotectant removal.

Method C: ${ }^{13}$

Step I : The blastocyst is immersed in 5\% glycerol in $\mathrm{B} 2$ medium $+10 \%$ serum for $10 \mathrm{mins}$

Step II : The blastocyst is transferred to $9 \%$ glycerol in B2 medium $+10 \%$ serum $+0.2 \mathrm{M}$ sucrose

Cooling is from R.T. to $-6^{\circ} \mathrm{C}$ at $-2^{\circ} \mathrm{C} / \mathrm{min}$, seeding followed by a $30 \mathrm{sec}$ delay and further cooling at $-0.3^{\circ} \mathrm{C} / \mathrm{min}$ to $-37^{\circ} \mathrm{C}$ followed by plunging into liquid nitrogen. Thawing is rapid in air at R.T. The glycerol is removed in 7 steps with decreasing concentrations of glycerol.

The results of survival of blastocysts after freeze-thawing and pregnancy rates pertransfer are summarised in Table 1.

Blastocysts were usually thawed 118 to 132 hours after the Luteinizing Hormon (LH) surge (Day 4 after ovulation) or 132 to 135 hours after HCG administration. Embryo replacement is performed only after blastocyst re-expansion. The culture period thus varies from a few hours to overnight ( 2 to 20 hour). ${ }^{12}$

Studies on the cryopreservation of blastocysts are quite limited. However, the few reports available all confirm that cryopreservation of blastocysts with glycerol can result in full term pregnancies. Interestingly an improvement in embryo quality and pregnancy rate was reported with the simultaneous use of sucrose and a reduction in the steps for the preparation of blastocysts before freezing. ${ }^{13}$ The increased number of cells per blastocyst may lessen the likelihood of freezing damage, since if a few cells are damaged, there would be many other cells to compensate by mitosis. This would be a major advantage of freezing blastocysts over other stages.

It has been claimed that expanded blastocysts gave the best results for freezing over the early cavitational stages and thus expansion was used as one of the main criteria when storing blastocysts. ${ }^{11}$ On exposure to glycerol the blastocyst usually contracts and some become pale or lyse after glycerol exposure. Many blastocysts have damaged blastomeres after thawing. Most blastocysts remain contracted when thawed, no cavity being visible and they contract even further during removal of the glycerol. Contraction was reversed after the complete removal of glycerol, the blastocysts eventually undergoing re-expansion.

Fehilly et al $^{12}$ concluded from their study that two thirds of thawed blastocysts reexpanded and were suitable for replacement compared with only one third for thawed cleaving embryos (earlier stages). The implantation rate was also quite high for blastocysts, with $35 \%$ of all patients who had blastocysts thawed becoming pregnant. These authors claimed that blastocyst freezing may be a superior method and the longer period of culture required for embryos to reach the blastocyst stage may act as a quality control to select those unable to display continued growth. Evidence has suggested that prefreeze development in vitro, assessed by morphologic examination and rate of development is an important parameter in embryo survival and establishment of pregnancy. ${ }^{14}$

Table 1. Pregnancy rates after transfer of frozen thawed blastocysts

\begin{tabular}{ccccc}
\hline Method & $\begin{array}{c}\text { No of } \\
\text { blastocysts } \\
\text { frozen-thawed }\end{array}$ & $\begin{array}{c}\text { Thaw survival } \\
\%(\mathrm{n})\end{array}$ & $\begin{array}{c}\text { Pregnancy } \\
\text { rate/transfer } \\
\%(\mathrm{n})\end{array}$ & Author \\
\hline A & 30 & $57(17)$ & $33(2 / 6)$ & 11 \\
$\mathrm{~A}$ & 38 & $66(25)$ & $53(8 / 15)$ & 12 \\
$\mathrm{~A}$ & 87 & $62(54)$ & $4(1 / 27)$ & 13 \\
B & 124 & $70(87)$ & $8(3 / 37)$ & \\
C & 289 & $75(216)$ & $21(21 / 101)$ & \\
\hline
\end{tabular}

\section{REFERENCES}

1. Society for Assisted Reproductive Technology, The American Fertility Society. Assisted reproductive technology in the United States and Canada: 1991 results from the Society for Assisted Reproductive Technology generalised 
from the American Fertility Society Registry. Fertil Steril 1993; 59:956-62.

2. Dokras A, Sargent IL, Barlow DH. Human blastocyst grading: an indicator of development potential? Human Reprod 1993; 8:2119-27.

3. Hardy K. Development of human blastocysts in vitro. In : Ed Bavister BD Preimplantation embryo development. Serono Symposia USA, Norwell, Massachusetts, Springer-Verlag 1994; 184-99.

4. Bolton VN, Wren ME, Parsons JH. Pregnancies after in vitro fertilization and transfer of human blastocysts. Fertil Steril 1991; 55:830-2.

5. Menezo Y, Hazout A, Dumont M, Herbaut N, Nicollet B. Coculture of embryos on Vero cells and transfer of blastocysts in human. Hum Reprod 1992; 72:101-6.

6. Frydman R, Freitas L, Lelaldler C Olivennes F. What are the main indications for coculture in an IVF program: a one year experience. J Asst Reprod Genet (Suppl) 1993; 10:55 (W3-5).

7. Bongso A, Ng SC, Fong CY, Anandakumar C, Marshall B, Edirisinghe R, Ratnam SS. Improved pregnancy rate after transfer of embryos grown in human fallopian tubal cell coculture. Fertil Steril 1992; 58:569-74.
8. Sjogren A, Sjoblom P, Hamberger L. Culture of human spare embryos: association between blastocyst formation and pregnancy. J Asst Reprod Genet 1992; 9:41-4.

9. Al-Hasani S, Diedrich K, Van der Ven $\mathbf{H}$, Bauer O, Hartje $M, K r e b s$ D. The incidence of pregnancy following sequential embryo transfer. Proc VII World Congress Human Reprod, Helsinki, 1990; Abstr 156.

10. Edwards RG, Hollands P. New advances in human embryology: implications of the preimplantation diagnosis of genetic diseases. Hum Reprod 1988; 3:549-56.

11. Cohen J, Simons RF, Edwards RG, Fehilly CB, Fishel SB. Pregnancies following the frozen storage of expanded human blastocysts. J In Vitro Fert Embryo Transfer 1985; 2:59-64.

12. Fehilly CB, Cohen J, Simons RF, Fishel SB, Edwards RG. Cryopreservation of cleaving embryos and expanded blastocysts in the human: a comparative study. Fertil Steril 1985; 44:683-744.

13. Menezo Y, Nicollet B, Herbaut N, Andre D. Freezing cocultured human blastocysts. Fertil Steril 1992; 58:977-80.

14. Hartshome GM, Elder K, Crow J, Dyson H, Edwards RG. The influence of in vitro development upon post-thaw survival and implantation of cryopreserved human blastocysts. Hum Reprod 1991; 6:136-41. 